Мамич М., Шевченко-Бітенська О. Поняття "менеджмент" і "управиіння"

УДК 81'37

DOI https://doi.org/10.24919/2308-4863/34-3-20

Мирослава МАМИЧ, orcid.org/0000-0002-2868-3953

доктор філологічних наук, професор, завідувач кафедри прикладної лінгвістики Національного університету «Одеська юридична академія»

(Oдеса, Україна) miroslavamiros@ukr.net

ОЛЕНа ШЕВЧЕНКО-БІТЕНСЬКА, orcid.org/0000-0002-0845-3114 кандидат юридичних наук, дочент, викладач кафедри іноземних мов № 1 Національного університету "Одеська юридична академія» (Oдеса, Україна) shevchenkobitenskaya@gmail.com

\title{
ПОНЯТТЯ «МЕНЕДЖМЕНТ» І «УПРАВЛІННЯ» В ЗАКОНОДАВЧОМУ ПІДСТИЛІ УКРАЇНСЬКОЇ МОВИ: СЕМАНТИКА, КОНЦЕПТУАЛЬНЕ НАПОВНЕННЯ
}

Стаття присвячена проблемі диферениіації лексичної семантики за сферами культури повсякдення. Наголошено на зв'язку останньої з мовою спеціального призначення, щзо наводить дослідника на думку, щзо мова диференційована соціофункиіонально і поняття активного та пасивного словника у проєкції на загальну та функиіонально-стильові сфери різняться. Відповідно, запропоновано вивчення такої диференціації $і$ в мові законодавства, щео є вираженням публічної діяльності органів влади, ї̈ офіиійної комунікації з національною спільнотою, пов 'язаної з актуалізацією епістеміологічних концеептів (СИСТЕМА, СТРУКТУРА, ФУНКЦІЯ, СУБ'СКТ, ОБ'СКТ тощо) та спещифікованих правових конщептосфер (середовищ формування та вживання спеціальних термінів у тій чи іншій підгалузі законодавства).

Запропоновано розвивати лінгвоконцептологічний ракурс дослідження з метою осмислення сучасних інтернаціональних і національних термінологічних систем та підсистем, соиіокультурних комунікативних сфер, термінологічної компетенції комунікантів. Підкреслено, щзо поєднання ж його із традиційним структурно-семантичним аналізом уможливлює подальше уточнення лексичних норм сучасної украӥнської літературної мови.

Проведений аналіз ономасіологічного потенціалу понять «менеджмент» та «управління» в текстах українського законодавства XXI cm. пов 'язаний із виявленням системи термінологічних сполук у текстах законодавчого підстилю украӥнської мови з базовими поняттями «менеджмент» та «управління», аналізом семантичного змісту ичих словосполучень і встановленням їх кореляції з базовими епістеміологічними концептами та правовими концептосферами, з виявленням типових когнітивно-вербальних, лексико-граматичних моделей функціонування понять «менеджмент» та «управління» в спеціалізованій мові законодавства.

Відповідно до проведеного дослідження зроблено висновок, щзо фахова мова у сфері управління перебуває в стані постійного розвитку, розширення поняттєвого та концептуального наповнення, кореляції з епістеміологічними концептами та правовими концептосферами. Дослідження сучасних законодавчих текстів уможливлює своєчасне відстеження активних структурно-семантичних, структурно-граматичних змін у термінологічній cфepi.

Ключові слова: мова законодавства, мова спеціального призначення, термін, концепт, концептосфера. 
Myroslava MAMYCH, orcid.org/0000-0002-2868-3953 Doctor of Philological Sciences, Professor, Head of the Department of Applied Linguistics National University "Odessa Law Academy" (Odessa,Ukraine) miroslavamiros@ukr.net

Olena SHEVCHENKO-BITENSKA, orcid.org/0000-0002-0845-3114

Candidate of Law, Associate Professor, Lecturer at the Department of Foreign Languages № 1 National University "Odessa Law Academy" (Odessa, Ukraine) shevchenkobitenskaya@gmail.com

\title{
THE CONCEPT OF "MANAGEMENT" AND "ADMINISTRATION" IN THE LEGISLATIVE BACKGROUND OF THE UKRAINIAN LANGUAGE: SEMANTICS, CONCEPTUAL FILLING
}

\begin{abstract}
The article is devoted to the problem of lexical semantics differentiation by spheres of everyday culture. The connection of the latter with the special purpose language is emphasized, which leads the researcher to think that the language is sociofunctionally differentiated and the concepts of active and passive vocabulary in the projection on the general and functional-stylistic spheres differ. Respectively, it is proposed to study such differentiation also in the language of legislation, which is an expression of public activity of public authorities, its official communication with the national community related to the actualization of epistemological concepts (such as SYSTEM, STRUCTURE, FUNCTION, SUBJECT, OBJECT, etc.) and specified legal conceptospheres (environments of formation and use of special terms in one or the other sub-branch of the legislation).

It is proposed to develop the linguo-conceptual perspective of the research for understanding modern international and national terminological systems and subsystems, socio-cultural communicative spheres, terminological competence of communicators. It is emphasized that its combination with the traditional structural-semantic analysis allows further clarification of the lexical norms of the modern Ukrainian literary language.

An analysis of the onomasiological potential of the concepts of "management" and "administration" in the texts of Ukrainian legislation of the XXI century associated with the identification of a system of terminological compounds in the texts of the legislative background of the Ukrainian language with the basic concepts of "management" and "management", analysis of the semantic content of these phrases and their correlation with basic epistemological concepts and legal conceptospheres, with the identification of typical cognitive-verbal-grammatical models of functioning of the concepts "management" and "administration" in the specialized language of legislation.

According to the study, it was concluded that the professional language in the field of management is in a state of constant development, expansion of conceptual and conceptual content, correlation with epistemological concepts and legal conceptospheres. The study of modern legislative texts allows timely tracking of active structural-semantic, structural-grammatical changes in the terminological sphere.
\end{abstract}

Key words: language of legislation, language of special purpose, term, concept, conceptosphere.

Постановка проблеми. Диференціація лексичної семантики за сферами культури повсякдення одна 3 важливих проблем сучасної комунікації. Загальномовні та термінологічні спеціалізовані словники дають приблизну картину розрізнення значень лексем і створених на їх базі словосполучень, ієрархії лексичних значень у структурі сучасного знання про світ, що його загалом відбиває когнітивна та вербальна картини світу. Зв'язок сфери культури повсякдення із мовою спеціального призначення (за іншою термінологією - професійною мовою, фаховою мовою, технічною мовою, спеціалізованою підмовою (субмовою), професійним жаргоном, офіційною мовою) очевидний. Насамперед він наводить дослідника на думку, що мова диференційована соціофункціо- нально і поняття активного та пасивного словника у проєкції на загальну та функціонально-стильові сфери різняться. Така диференціація простежується і в мові законодавства, або законодавчому підстилі офіційно-ділового різновиду української літературної мови, що представлений писемними текстами - законами та підзаконними актами.

Останні є вираженням публічної діяльності органів влади, іiі офіційної комунікації з національною спільнотою, пов'язаної з актуалізацією загальнофілософських епістемічних концептів (СИСТЕМА, СТРУКТУРА, ФУНКЦІЯ, СУБ'ЄКТ, ОБ'ЄКТ тощо) та специфікованих правових концептосфер (середовищ формування та вживання спеціальних термінів у тій чи іншій підгалузі законодавства). 
Насамперед нашу увагу привертають актуальні поняття «менеджмент» / «управління», оскільки в сучасній мовній практиці в різних сегментах культури повсякдення спостерігаємо розростання лексичної (термінологічної) сполучуваності відповідних слів, вважаємо за необхідне зіставити їхнє змістове наповнення в ракурсі спеціалізації семантики у сфері публічного управління, яку охопив законодавчий підстиль української літературної мови.

Запропонований лінгвоконцептологічний ракурс дослідження актуальний для осмислення сучасних інтернаціональних і національних термінологічних систем та підсистем, соціокультурних комунікативних сфер, термінологічної компетенції комунікантів (Стасюк, 2013), поєднання ж його $з$ традиційним структурно-семантичним аналізом уможливлює подальше уточнення лексичних норм сучасної української літературної мови.

Аналіз досліджень. За останні 10 років в Україні намітилися певні зрушення в осмисленні проблем - встановлення та опису підгруп мов спеціального призначення. Тут погоджуємося 3 узагальненням В. Л. Іващенко, яка наголосила на актуальності дискурсивних аспектів термінознавства, зокрема інтегративної концепції професійного дискурсу та когнітивно-комунікативної теорії термінологічної номінації (Іващенко, 2018: 56). Беремо до уваги наукові позиції В. Л. Іващенко (Іващенко, 2006), Л. В. Туровської (Туровська, 2011), Л. Півньової (Півньова, 2014) та ін. щодо сформованості в українській мові спеціалізованих лексиконів, потреби їх дослідження в соціолінгвістичному, лінгвокогнітивному, функціонально-стильовому, термінографічному аспектах. Це уможливлює кореляцію синхронного та діахронного поглядів на мови спеціального призначення, на розвиток зіставного термінознавства не лише в рамках національної культури повсякдення, але й у ракурсі вивчення лінгвокогнітивних механізмів ономасіології в підмовах спеціалізованих сфер функціонування української літературної мови. Огляд літератури із заявленої проблеми засвідчує увагу до вживання понять «менеджмент» та «управління» в українській та інших мовах (Штайн, 2010).

Мета статті-проаналізуватиономасіологічний потенціал понять «менеджмент» та «управління» в текстах українського законодавства XXI ст. Серед завдань нашого дослідження - виявлення системи термінологічних сполук у текстах законодавчого підстилю української мови з базовими поняттями «менеджмент» та «управління», аналіз семантичного змісту цих словосполучень і встановлення їх кореляції з базовими епістемічними концептами та правовими концептосферами, виявлення типових когнітивно-вербальних, лексико-граматичних моделей функціонування понять «менеджмент» та «управління» у спеціалізованій мові законодавства.

Виклад основного матеріалу. У парі понять «менеджмент» та «управління», звичайно, перше $€$ актуальним, сучасним. Це слово відоме в українській суспільно-політичній, соціально-економічній мовній практиці від 90-х років XX ст. Перехід від «уживання» до «термінологізації» слова «менеджмент» супроводжував процес текстової та словникової кодифікації.

Якщо йти за лексикографічними загальномовними джерелами, які першими зафіксували лексему «менеджмент» (1999-2005 рр.), то загалом укладачі орієнтують загал на те, що вона вживається у двох значеннях: 1) Сукупність принципів, методів, засобів і форм управління виробництвом із метою підвищення його ефективності, збільшення прибутків. Кредитний менеджмент - процес управління дебіторською заборгованістю підприємства, метою якого є забезпечення своєчасної інкасації боргу. Фінансовий менеджмент - система, принципів, методів і форм організації грошових відносин; 2) керівництво підприємства, фірми; керівний орган (Великий, 2005). Йдеться про соціально-економічну сферу культури повсякдення. У 2015 р. під впливом розвитку освітнього процесу і розширення спеціалізацій менеджменту загальномовні словники вже виділили третє значення - «наука про управління організаціями».

Натомість законодавчий підстиль (фіксація в 11 текстах) засвідчує доволі вузьке коло термінологічних словосполучень, узгоджених із міжнародною LSP, а саме: менеджмент з енергозбереження, менеджмент повітряного простору (ASM - Airspace Management), менеджмент у соціальній роботі з сім 'ями, дітьми та молоддю, менеджмент якості. Якщо словники загальної мовної практики зафіксували поняття «менеджмент» на межі століть, то законодавство України кодифікувало його значно раніше через практичні, суспільні фактори від середини 90-х рр. ХХ ст., засвідчивши, що процес термінологізації охопив правові концептосфери ЗА ВИДОМ ДІЯЛЬНОСТІ СОЦІУМУ, а саме: енергетики (Менеджмент $з$ енергозбереження - система управління, спрямована на забезпечення рачіонального використання споживачами паливно-енергетичних ресурсів (Закон України «Про енергозбереження», 1994 р.), а пізніше і соціального управління (Менеджмент у соціальній роботі з сім'ями, 
дітьми та молоддю - управління системою соиіальноїроботиз сім'ями, дітьми тамолоддю, спрямоване на реалізацію ї̈ завдань та пошук оптимальних шляхів їх вирішення (Закон України «Про соціальну роботу з сім'ями, дітьми та молоддю», 2001 р.), авіації (Менеджсмент повітряного проcmopy (ASM - Airspace Management) - функиія планування, основною метою якої є забезпечення максимального використання наявного повітряного простору на основі динамічного розподілу за часом та, в окремих випадках, резервування повітряного простору для різних категорій користувачів із метою задоволення короткострокових потреб (з Інструкції Державіаслужби, 2006 р.), Менеджмент якості-скоординована діяльність з контролю та управління організачією щодо якості (з Правил Державіаслужби, 2019 р.). (Перелік галузей, де застосовуються термін менеджмент, насправді ширший, але законодавчий підстиль не охоплює їх як правові концептосфери).

Наведені аргументи ще раз підкреслюють, що кодифікація - синергетичний процес, який охоплює ужитково-текстовий і лексикографічнотезаурусний рівні комунікації, формується в них, закріплюючись у загальній мовній практиці на певний час. Лише створення функціональностильового паспорту слова, терміна (Чернобров, 2017) уможливлює висновки про кодифікацію, про ії часову динаміку.

Мова законодавства (див. https://zakon.rada. gov.ua/laws/term/u/page2/name) регламентує когнітивно-вербальне співвідношення понять «менеджмент» та епістеміологічних концептів управління, планування, координація, діяльність. Пор. наведене твердження за такими цитатами з визначеннями: Планування - прочес розробки порядку виконання певної діяльності, тобто конкретизаиія иієї діяльності: визначення проміжних иілей i послідовності їх досягнення, розрахунку термінів, прогнозування наслідків майбутніх ситуачій, визначення потреб у ресурсах, виконавиях $і$ необхідних засобах за кожною з иих иілей (МОН України, 2004 р.); планування якості - встановлення иілей у сфері якості, визначення прочесів системи управління якістю, необхідних для досягнення иілей у сфері якості (з Вимог Держатомрегулювання України, 2008 р.); координація - управлінська функція Державної прикордонної служби України, щзо об'єднує й систематизує зусилля контрольних органів і служб для забезпечення пропуску через державний кордон осіб, транспортних засобів та вантажів у відповідності до технологічних схем пропуску (з Порядку Адміністрація Держкордонслужби, 2011 р.). Тобто йдеться про цілеспрямовану, продуману публічну діяльність у тій чи іншій сфері культури повсякдення.

Поняття «управління» в українській мові має виразну віддієслівну семантику - перше і третє значення від назв дій «управляти», «керувати». Друге ж значення - «адміністративна установа або відділ якоїсь установи, організації, що відає певною галуззю господарської, наукової, військової і т. ін. Діяльності» (СУМ 10: 468). Сучасне законодавство зафіксувало такі приклади уживання слова «управління» у другому знач. - загальні для функціональної офіційно-ділової сфери назви об'єктів - державних установ: Управління цивільно-військового співробітництва Збройних сил України, Управління військовими частинами, Управління Державного казначейства, Управління Державного казначейства головних управлінь Державного казначейства Украйни, Управління державної охорони Украӥни.

Більш давня практика вживання сприяла виформуванню в українській літературній мові понад 300 термінологічних сполук, що зафіксовані в базі законодавчого підстилю. Одну групу терміновживань законодавчого підстилю формує правова концептосфера СФЕРА ДІЯЛЬНОСТІ. Тому актуальні для сучасного офіційно-ділового стилю словосполучення у сфері техніки i транспорту (управління аварією, управління аеронавігачійною інформачією, управління безпекою (руху; на транспорті; судноплавства на морському і річковому транспорті), управління використанням (менеджмент) повітряного простору; управління військовими перевезеннями водним транспортом; управління повітряним рухом, управління польотами; управління рухомим об'єктом; управління перевантаженнями; оперативно-технічне управління), у сфері ресурсів (управління відпрацьованим паливом; управління радіоактивними відходами), економіки та банківської справи (управління державним (місцевим) боргом, управління державним боргом та гарантованим державою боргом; управління іпотечним покриттям, управління іпотечними активами; управління активами (i пасивами), управління активами та зобов'язаннями; управління бюджетними коштами; управління майном (фінансовими активами), управління місиевими фінансами; управління об'єктами державної власності; управління операчійним ризиком), у сфері житлового господарства (управління багатоквартирним будинком), у військовій сфері (управління інформачією у сфері протимінної діяльності; управління матеріально-технічного забезпечення БМД, управління мобілізащією, управління якістю 
розмінування), у сфері інформації (управління ключовими даними, управління ключовими даними y сфрері криптографічного захисту інформачії, управління конфігурацією; управління номерним ресурсом мереж електрозв 'язку загального користування України), охорони здоров'я, соціального забезпечення (управління старінням), охорони довкілля (управління охороною навколишнього природного середовища), у сфері публічної діяльності (управління проєктом; управління ризиками, управління ризиками для якості; управління системними обмеженнями, управління статусом сертифіката, управління якістю, управління, на яке покладений контроль; управління ресурсом).

Як і слово-термін «менеджмент», поняття «управління» співвіднесене з ширшими за семантикою, такими, що перебувають у родо-видових відношеннях, одиницями - вербалізаторами епістеміологічних концептів ФУНКЦІЯ (наприклад: управління - функція організованих систем, щьо забезпечує збереження їх структури, підтримку режиму діяльності, досягнення їх мети (з наказу $\mathrm{MOH} \mathrm{України} \mathrm{про} \mathrm{галузеві} \mathrm{стандарти} \mathrm{освіти,}$ 2004 р.); управління - функція керуючої системи, метою якої є наближення стану, положення, властивостей об'єкта управління та/або характеристик їх змінювання у часі до таких, щзо в циих умовах вважаються потрібними або найкращиими (з Вимог $з$ ядерної та радіаційної безпеки Держатомрегулювання, 2015 р.), СИСТЕМА (Система управління - сукупність взаємопов'язаних або взаємодіючих елементів, яка дає змогу встановити політику та завдання і досягати иих завдань (з Положення Мінтрансзв'язку України, 2004 р.)), СТРУКТУРА (управління-структурний підрозділ місиевої державної адміністрації одногалузевого або однофункиіонального спрямування, до складу якого входить не мени як два самостійних відділи (з Постанови Кабміну, 2005 р.), ЕЛЕМЕНТ - СКЛАДНИК (органи управління - установи, організаиії, підприємства та їх структурні підрозділи, щчо мають право приймати управлінські рішення в межах своєї компетениї̈ $і$ контролювати виконання прийнятих рішень (з Положення Мінтрансу України, 2003 р.); пункт управління сукупність робочих місиь, розташованих у захищених спорудах, будівлях або на рухомих засобах та призначений для роботи оперативного складу органів військового управління (частин, ДССЗ3І) під час управління військами (силами) (з наказу Служби безпеки України, 2005 р.).

Важливі антропоцентричні характеристики управління пов'язані із вербалізацією епістеміологічного концепту СУБ'ЄКТ, а саме: суб'єкти управління - персонал, структурні підрозділи, спеціально створені органи, які впливають на систему управління з метою забезпечення ії функиіонування (із Положення Мінтрансу України, 2003 р.), установник управління - власник (клієнт), який передає управителю в управління об'єкт (об'єкти) управління (із Рішення Держкомісцінних паперів, 2006 р.), група управління проєктом - окремий структурний підрозділ відповідального виконавия або бенефіціара чи група консультантів, уповноважені відповідальним виконавием або бенефіціаром згідно з його ріменням або договорами між відповідальним виконавием або бенефічіаром та фізичними особами-консультантами забезпечувати здійснення заходів з підготовки та реалізації проекту згідно з договором України з МФО, договором між МФО і бенефічіаром, договором між Мінфіном $i$ бенефіціаром та/або відповідальним виконавцем (з Постанови Кабміну України, 2008 р.), установник управління майном (далі - установник) - особа, яка передає майно управителю в довірчу власність на підставі договору управління майном. У иьому Законі для ФФБ - ие довіритель, при емісії сертифікатів ФОН - ие власник сертифікатів ФОН (із Закону України «Про фінансово-кредитні механізми і управління майном при будівництві житла та операціях 3 нерухомістю», 2003 р.), орган управління територіальною підсистемою - орган виконавчої влади або його структурний підрозділ, призначений для безпосереднього керівництва діяльністю щодо запобігання і реагування на надзвичайні ситуаиіï в межах їх компетениії (із Положення МНС України, 1998 р.) та ін.

За просторовими ознаками управління включене в концептосферу ТЕРИТОРІЯ - РЕГІОН, як-от: територіальні управління - філї̈ Національного банку та Операчійне управління Наџіонального банку (з Постанови Нацбанку України, 2004 р.), міжрегіональні управління - міжрегіональні управління з питань виконання кримінальних покарань та пробаиії Міністерства юстиції України (з наказу Мін'юсту України, 2019 р.), басейновий принцип управління - комплексне (інтегроване) управління водними ресурсами в межах району річкового басейну (з Водного кодексу України, 1995 р.) тощо.

В останні роки набуває активності поняття «публічне управління», кодифіковане в законодавчому підстилі української мови (близько 30 документів 2005-2019 рр.) 3 орієнтацією на застосування законів, принципів, методів, технологій та процедур в управлінні суб'єктами публічної сфери, 
що забезпечить європейський рівень надання адміністративних послуг на засадах запровадження у практику діяльності принципів демократичного врядування, із потрактуванням його як владного впливу на життєздатність людей із боку органів державної влади, місцевого самоврядування та громадських організацій шляхом застосування сукупності методів (економічних, адміністративних, інформаційно-психологічних та ін.) із метою досягнення цілей суспільного розвитку.

Висновки. Фахова мова у сфері управління перебуває в стані постійного розвитку, розши- рення поняттєвого та концептуального наповнення, кореляції з епістеміологічними концептами та правовими концептосферами. Дослідження сучасних законодавчих текстів уможливлює своєчасне відстеження активних структурно-семантичних, структурно-граматичних змін у термінологічній сфері. За нашими спостереженнями, хоча поняття «менеджмент» актуальне, але через його неорганічність в українськомовній структурі не набуває такого структурно-граматичного, валентнісного розширення, як поняття «управління», зміст якого відбиває активні суспільні зміни.

\section{СПИСОК ВИКОРИСТАНИХ ДЖЕРЕЛ}

1. Великий тлумачний словник сучасної української мови / Уклад. і голов. ред. В. Т. Бусел. Київ : Ірпінь : ВТФ «Перун», 2005. $1728 \mathrm{c}$.

2. Верховна Рада України. Законодавство України. URL: https://zakon.rada.gov.ua/laws/main/index

3. Іващенко В. Л. Концептуальна репрезентація фрагментів знання в науково-мистецькій картині світу (на матеріалі української мистецтвознавчої термінології). Київ, 2006. 328 с.

4. Іващенко В. Л. Сучасне українське теоретичне термінознавство: віхи становлення. Слов'янське термінознавство кіния XX- початку XXI століть. Київ, 2018. С. 31-74.

5. ПівньоваЛ.Моваспеціальногопризначення якоб’єктлінгвістичнихстудій. Українськамова.2014.№ 4.С.117-125.

6. Словник української мови: в 11 томах. Київ, 1970-1980.

7. Стасюк Т. В. Основні метапоняття соціокогнітивного термінознавства: терміноконцепт. Publishing house Education and Science s.r.o. URL: http://www.rusnauka.com/1_NIO_2013/Philologia/3_124921.doc.htm

8. Туровська Л. Термінознавство і мова спеціального призначення: зони перетину. Термінологія документознавства та суміжних галузей знань : збірник наук. пр. Київ, 2011. Вип. 5. С. 33-38.

9. Чернобров Ю. Історичний паспорт синтаксичного терміна: джерела формування в XVI - I пол. XX ст. Украӥнська мова. 2017. № 1. С. 102-113.

10. Штайн У. Б. Порівняльний аналіз утворення та вживання терміну «менеджмент» в англійській та українській мовах. Наукові записки. Серія «Філологічна». 2010. Вип. 15. С. 342-346.

\section{REFERENCES}

1. Velykyi tlumachnyi slovnyk suchasnoi ukrainskoi movy [Large explanatory dictionary of the modern Ukrainian language] / Ed. V.T. Busel. Kyiv : Irpin: VTF "Perun", 2005. 1728 p. [in Ukrainian].

2. Verkhovna Rada Ukrainy. Zakonodavstvo Ukrainy [The Verkhovna Rada of Ukraine. Legislation of Ukraine]. URL: https://zakon.rada.gov.ua/laws/main/index [in Ukrainian].

3. Ivashchenko V. L. Kontseptualna reprezentatsiia frahmentiv znannia v naukovo-mystetskii kartyni svitu (na materiali ukrainskoi mystetstvoznavchoi terminolohii). [Conceptual representation of fragments of knowledge in the scientific and artistic picture of the world (on the material of Ukrainian art terminology)]. Kyiv, 2006. 328 p. [in Ukrainian].

4. Ivashchenko V. L. Suchasne ukrainske teoretychne terminoznavstvo: vikhy stanovlennia [Modern Ukrainian theoretical terminology: milestones]. Lavic terminology of the late twentieth - early twentieth centuries. Kyiv, 2018, pp. 31-74 [in Ukrainian].

5. Pivneva L. Mova spetsialnoho pryznachennia yak obiekt linhvistychnykh studii [Special purpose language as an object of linguistic studies]. Ukrainian language, 2014, № 4, pp. 117-125 [in Ukrainian].

6. Slovnyk ukrainskoi movy: v 11 tomakh [Dictionary of the Ukrainian language: in 11 volumes]. Kyiv: Naukova Dumka, 1970-1980 [in Ukrainian].

7. Stasiuk T. V. Osnovni metaponiattia sotsiokohnityvnoho terminoznavstva: terminokontsept [Basic metaconcepts of sociocognitive terminology: term concept]. Publishing house Education and Science s.r.o. URL: http://www.rusnauka. com/1_NIO_2013/Philologia/3_124921.doc.htm [in Ukrainian].

8. Turovska L. Terminoznavstvo i mova spetsialnoho pryznachennia: zony peretynu [Terminology and special purpose language: intersections]. Terminology of document science and related fields of knowledge: Coll. Science. Kyiv, 2011, Vol. 5, pp. 33-38 [in Ukrainian].

9. Chernobrov Yu. Istorychnyi pasport syntaksychnoho termina: dzherela formuvannia v XVI - I pol. XX ct. [Historical passport of the syntactic term: sources of formation in the XVI - I half. XX century]. Ukrainian language, 2017, № 1, pp. 102-113 [in Ukrainian].

10. Shtain U. B. Porivnialnyi analiz utvorennia ta vzhyvannia terminu "menedzhment" $v$ anhliiskii ta ukrainskii movakh [Comparative analysis of the formation and use of the term "management" in English and Ukrainian]. Proceedings. Philological series, 2010, Vol. 15, pp. 342-346 [in Ukrainian]. 